\title{
COMPRESSIVE STRENGTH MODEL FOR CONCRETE CONTAINING POLYETHYLENE TEREPHTHALATE (PET) BY USING ULTRASONIC PULSE VELOCITY
}

\author{
Rasha Jasim, \\ Assist. Lecture Department of Civil Engineering, University of Al-Qadisiyah, Iraq. \\ E-mail: Rasha.jasim@qu.edu.iq \\ Mohammed Qasim, \\ Assist. Lecture Department of Civil Engineering, University of Al-Qadisiyah, Iraq. \\ E-mail: mohammed.alkarawi@qu.edu.iq
}

Received on 31 July 2017 Accepted on 31 October 2017 Published on 30 December 2017

DOI: $10.30772 /$ jjes.v10i4.487

\begin{abstract}
This research proposed a model describing the relationship between ultrasonic pulse velocity (UPV) and the compressive strength test of concrete containing PET (Polyethylene terephthalate). This was achieved by measuring ultrasonic pulse velocity (UPV) on this type of concrete and comparing the result of compressive strength tests to clarify the accuracy of the ultrasonic test equation for this type of concrete. Waste bottles of water was used in this study by cutting them into laminar form of fibers with zigzag edges in different length $(1,2,3) \mathrm{cm}$ for each volume fraction of PET $(1 \%, 2 \%$ and $3 \%)$ by cement weight with fixed width $(0.5) \mathrm{cm}$. Then, they were incorporated with the concrete. It was noticed from the laboratory tests results that the relationship UPV - strength are related together in the volume fraction of $1 \%$ for the length $3 \mathrm{~cm}$ and the correlation factor $(R)$ is equal to 0.94. This indicates a very good exponential relationship between UPV and compressive strength. Also, the results are compared and discussed with another proposed formula that found in literature.
\end{abstract}

Keywords: Concrete contain PET, Non_ Destructive tests, Compressive strength, Ultrasonic wave velocity (UPV).

\section{INTRODUCTION}

Fibre-reinforced polymer (FRP) is the alternative techniques in modern life which in continuous progress by using it as a constituent of concrete in the construction industry. Significant research studied the destructive tests of concrete contains polyethylene terephthalate waste (PET) such as compressive strength, modules of elasticity, tensile strength and flexural strength. Moreover, these tests were examined in many of structural members like beams and columns. The ultrasonic techniques became popular within the civil engineering industry for a wide range of applications including the evaluation of concrete structures and pavements. It was used to evaluate the compressive strength of PET concrete. 


\section{AL-QADISIYAH JOURNAL FOR ENGINEERING SCIENCES}

Vol. 10, No. 4

ISSN: $1998-4456$

Benosman et al. (2016) studied the properties of PET-mortar composites by destructive and nondestructive testing with different ratio of fibre $(0 \%, 2.5 \%, 5 \%$ and $7.5 \%)$. They found The UPV values of the PET-Mortar composites and compressive strength decrease with an increase in the percentage of the PET waste particles content.

Lorenzi et al. (2007) created model between UPV and compressive strength test. They conducted an analysis for their results in order to understand how the results of UPV are affected by differences at concrete conditions. This can lead into a reduction of the mistakes considering the strength estimation. The results showed that there was a good correlation between compressive strength and UPV test.

Al-Nu'man et al. (2015) proposed the relationship formulas /curve between UPV and compressive strength for concrete having the collection from 18 to $55 \mathrm{MPa}$ of concrete strength. After analysing the data, they founded a good correlation between UPV and compressive strength of concrete.

Ammash et al. (2017) study the effect of using plastic waste on mechanical properties of concrete. noticed from laboratory tests that the addition of plastic fibres improves the compressive strength, tensile strength and modulus of rupture of concrete.

The aim of this research is to develop a model for the relationship between UPV and compressive strength for concrete containing Polyethylene terephthalate fibre, and calculate the correlation factor for all the results obtained. Different length of fibre was used $(1,2,3)$ for each fibre content (ratio) $(1,2,3) \%$. To determine which ratio gives the closest result between the compressive strength obtained from destructive and non-destructive tests in order to clarify the accuracy of the ultrasonic equation adopted in previous literature.

\section{EXPERIMENTAL WORK}

In the experimental work, 30 cubes were cast and tested in the laboratory to find the compressive strength for destructive and non-destructive tests of concrete, for different waste ratios. The dimensions of cubes were $(150 \times 150 \times 150)$. The age of the test for all samples was 28 days. All the materials used in this study were tested and compared according to the Iraqi Standard Specification Requirements. The tested materials are:

\subsection{CEMENT}

Ordinary Portland cement was used in the experimental work. The chemical and physical tests were conducted in the construction laboratory of concrete /Engineering collage/ University of Al-Qadisiyah . The results satisfied to Iraqi Specification No.5/1984. The outcomes of the test are shown in Table 1.

Table 1: Chemical Analysis and Physical Test Results of Cement

\begin{tabular}{|c|c|c|}
\hline \multicolumn{3}{|c|}{ Chemical Test Results } \\
\hline Oxide & Percent weight & Iraqi Specification \\
\hline $\mathrm{SiO}_{2}$ & 21.3 & - \\
\hline $\mathrm{CaO}$ & 64.64 & - \\
\hline $\mathrm{MgO}$ & 2.62 & $\leq 5 \%$ \\
\hline $\mathrm{Fe}_{2} \mathrm{O}_{3}$ & 2.58 & - \\
\hline $\mathrm{Al}_{2} \mathrm{O}_{3}$ & 6.16 & - \\
\hline Loss on ignition & 3 & $\leq 4 \%$ \\
\hline Irresolvable material & 1.5 & $\leq 1.5 \%$ \\
\hline
\end{tabular}




\section{AL-QADISIYAH JOURNAL FOR ENGINEERING SCIENCES}

Vol. 10 , No. 4

ISSN: $1998-4456$

\begin{tabular}{|c|c|c|}
\hline \multicolumn{3}{|c|}{ Physical Test Results } \\
\hline Property & Results & Iraqi Specification \\
\hline Soundness (Autoclave)\% & 0.02 & $\leq 0.8$ \\
\hline Initial setting time (min) & 85 & $\geq 45$ \\
\hline Final setting time (min) & 260 & $\leq 600$ \\
\hline \multicolumn{2}{|c|}{ Compressive strength (MPa) } \\
\hline 3 days & 16.3 & $\geq 15$ \\
\hline 7 days & 23.7 & $\geq 23$ \\
\hline
\end{tabular}

\subsection{FINE AGGREGATE}

This material was tested and used in the mixture of concrete according to the Iraqi Specification No.45/1984. The results of fine aggregate test were within zone 2 as shown in the Table 2.

Table 2: Grading of Fine Aggregate Test

\begin{tabular}{|l|l|l|}
\hline Sieve size & \% of pass & Iraqi specification \\
\hline $4.75(\mathrm{~mm})$ & 100 & $90-100$ \\
\hline $2.36(\mathrm{~mm})$ & 84 & $75-100$ \\
\hline $1.18(\mathrm{~mm})$ & 68.7 & $55-90$ \\
\hline 600 micron & 37.5 & $35-59$ \\
\hline 300 micron & 9 & $8-30$ \\
\hline 150 micron & 2.6 & $0-10$ \\
\hline $\mathrm{SO}_{3}$ salt & Result & Iraqi specification \\
\hline $\mathrm{SO}_{3}(\%)$ & 0.16 & $\leq 0.5 \%$ \\
\hline
\end{tabular}

\subsection{Coarse Aggregate}

According to Iraqi Specification No.45/1984, The Shattered Coarse Aggregate was used in the mixture and tested. The results of the test are shown in Table 3 bellow.

Table 3: Grading of Coarse Aggregate Test

\begin{tabular}{|l|l|l|}
\hline Sieve size & \% of pass & Iraqi specification \\
\hline $37.5(\mathrm{~mm})$ & 100 & 100 \\
\hline $20(\mathrm{~mm})$ & 100 & $75-100$ \\
\hline $12.5(\mathrm{~mm})$ & 88.50 & - \\
\hline $9.5(\mathrm{~mm})$ & 33.59 & $30-6$ \\
\hline
\end{tabular}




\section{AL-QADISIYAH JOURNAL FOR ENGINEERING SCIENCES}

Vol. 10 , No. 4

ISSN: $1998-4456$

\begin{tabular}{|l|l|l|}
\hline $4.75(\mathrm{~mm})$ & 0.5 & $0-10$ \\
\hline $2.36(\mathrm{~mm})$ & 0.07 & - \\
\hline $\mathrm{SO}_{3}$ salt & Result & Iraqi specification \\
\hline $\mathrm{SO}_{3}(\%)$ & 0.09 & $\leq 0.1 \%$ \\
\hline
\end{tabular}

\subsection{Plastic Fiber}

Waste bottles of water were used by cutting them into small fibers with zigzag edges in different length $(1,2,3) \mathrm{cm}$ for each ratio of PET $(1 \%, 2 \%$ and $3 \%)$ by cement weight with fixed width $(0.5) \mathrm{cm}$. Then, they were added to the concrete mixes. (Figure 1 and 2).

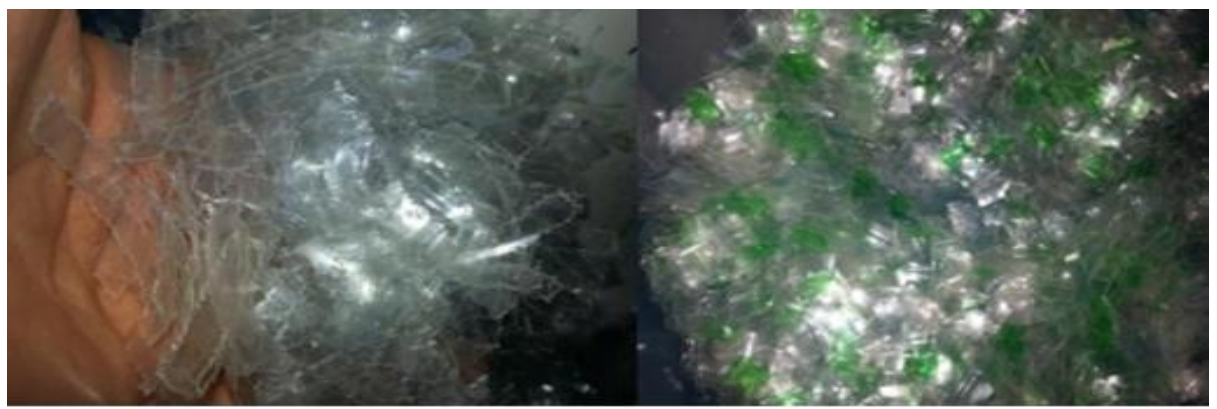

Figure 1: Formed Plastic Fibre

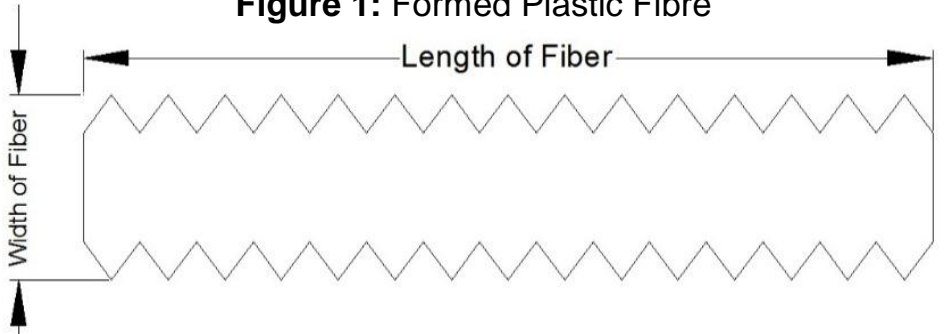

Figure 2: Type of Plastic Fibre

By using theory of Archimedes, the density of fibre was equal to $1.01 \mathrm{gm} / \mathrm{cm}^{3}$. As well as, many tests have been conducted by using tensile test machine such as yield stress, elongation and ultimate stress. The results of these tests were equal to $7.15 \mathrm{kN}, 8 \mathrm{~mm}$ and $8.25 \mathrm{kN}$ respectively.

\subsection{MIXING, CASTING AND CURING}

The concrete reference mix consists of cement, sand and coarse aggregates with no fiber. The dry materials were mixed together then; the plastic fiber were gradually added to the mix to avoid blocking of concrete. Finally, the water was added to the dry materials and the mixing continued to produce homogeneous mix. The fresh concrete was cast into the moulds immediately after mixing, in three layers for cube specimens.

\section{RESULT AND DISCUSSION}

The following laboratory tests were implemented in the University of Al-Qadisiyah / College of Engineering. 


\section{AL-QADISIYAH JOURNAL FOR ENGINEERING SCIENCES}

Vol. 10, No. 4

ISSN: $1998-4456$

\subsection{COMPRESSIVE STRENGTHS TEST} Table 4

the average of three specimens results from compressive strength test was recorded and listed in

\subsection{ULTRASONIC PULSE VELOCITY TEST}

Ultrasonic pulse velocity (UPV) test mainly measures the speed of electronic wave through composite concrete. the ultrasonic pulse velocity tests are summarized by placing transducers in the same direction in opposite face of each face as shown in the Figure (3) . This method is called direct transmission. It gives a more accurate results than other method. During the test, the ultrasonic waves are passing from one transducer to the other. The time of the traveling the waves was recorded from one surface to the other and measured the distance between the two faces of the cubes. In this way, the velocity of the ultrasonic wave can be calculated. The results of ultrasonic pulse velocity are listed in Table $\mathbf{5}$.

Table 4: Compressive Strength $\left(\mathrm{F}^{\prime} \mathrm{c}\right)$ for all Specimens $(\mathrm{MPa})$

\begin{tabular}{|c|c|c|c|c|c|c|c|c|c|}
\hline $\begin{array}{c}\text { Ref. } \\
\text { Mix }\end{array}$ & \multicolumn{3}{|c|}{$\begin{array}{c}\text { Compressive Strength } \\
\text { For 10 mm Fibre Length }\end{array}$} & \multicolumn{3}{c|}{$\begin{array}{c}\text { Compressive Strength } \\
\text { For } 20 \text { mm Fibre Length }\end{array}$} & \multicolumn{3}{c|}{$\begin{array}{c}\text { Compressive Strength } \\
\text { For } 30 \text { mm Fibre Length }\end{array}$} \\
\hline $0 \%$ & $1 \%$ & $2 \%$ & $3 \%$ & $1 \%$ & $2 \%$ & $3 \%$ & $1 \%$ & $2 \%$ & $3 \%$ \\
\hline 30.76 & 30.13 & 30.58 & 28.84 & 31.07 & 26.53 & 27.60 & 23.73 & 24.98 & 18.44 \\
\hline 31.24 & 30.89 & 27.73 & 29.64 & 30.76 & 29.51 & 28.98 & 26.27 & 30.71 & 16.89 \\
\hline 29.69 & 29.07 & 26.13 & 27.78 & 30.13 & 25.64 & 22.22 & 25.78 & 26.84 & 19.78 \\
\hline
\end{tabular}

Table 5: Ultrasonic Pulse Velocity for all Specimens $(\mathrm{m} / \mathrm{s})$

\begin{tabular}{|c|c|c|c|c|c|c|c|c|c|c|}
\hline \multirow{3}{*}{ Age } & $\begin{array}{c}\text { Ref. } \\
\text { Mix }\end{array}$ & \multicolumn{3}{|c|}{$\begin{array}{c}\text { UPV For } 10 \mathrm{~mm} \text { Fibre } \\
\text { Length }\end{array}$} & \multicolumn{3}{c|}{$\begin{array}{c}\text { UPV For } 20 \mathrm{~mm} \text { Fibre } \\
\text { Length }\end{array}$} & \multicolumn{3}{|c|}{$\begin{array}{c}\text { UPV For } 30 \mathrm{~mm} \text { Fibre } \\
\text { Length }\end{array}$} \\
\cline { 2 - 13 } & $0 \%$ & $1 \%$ & $2 \%$ & $3 \%$ & $1 \%$ & $2 \%$ & $3 \%$ & $1 \%$ & $2 \%$ & $3 \%$ \\
\hline \multirow{3}{*}{28 days } & 4.01 & 3.83 & 3.87 & 3.92 & 3.89 & 3.65 & 3.89 & 3.65 & 3.87 & 3.85 \\
\cline { 2 - 12 } & 3.88 & 3.73 & 3.95 & 3.88 & 3.78 & 3.85 & 3.84 & 3.88 & 3.85 & 3.88 \\
\cline { 2 - 11 } & 3.78 & 3.71 & 4.05 & 3.79 & 3.82 & 3.82 & 3.82 & 3.90 & 3.81 & 3.93 \\
\hline
\end{tabular}




\section{AL-QADISIYAH JOURNAL FOR ENGINEERING SCIENCES}

Vol. 10 , No. 4

ISSN: $1998-4456$

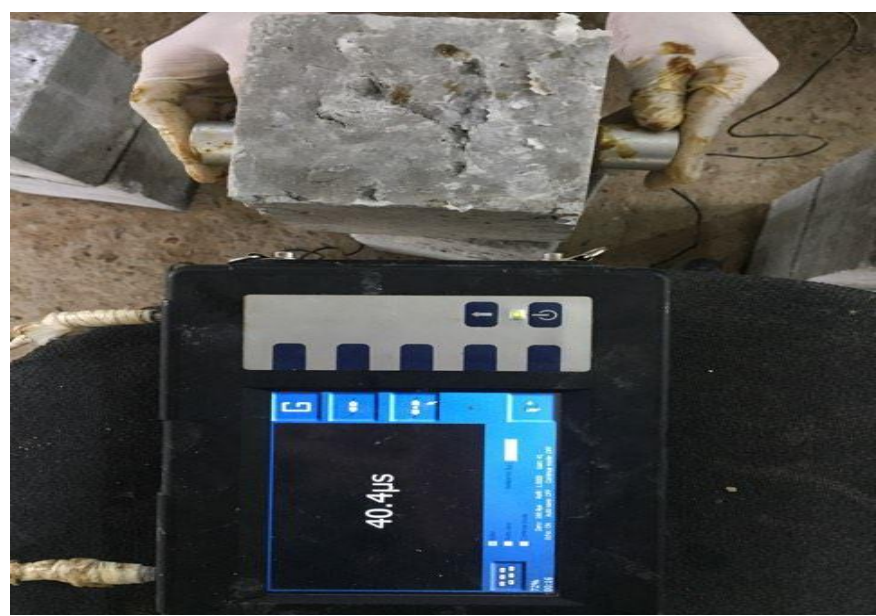

Figure 3: Ultrasonic Pulse Velocity Device

\section{THE RELATIONSHIOP BETWEEN COMPRESSIVE STRENGTH AND UPV}

The ultrasonic pulse velocity(UPV) can be related to compressive strength of concrete. Based on the value of the correlation coefficient $(R)$, the strength of the relationship varies. Thus, this relationship is used to classify the sample of the concrete containing PET.

For the length $1 \mathrm{~cm}$ with ratio $(1 \%, 2 \%)$ there is positive relationship, however this relationship is weak. While the ratio $3 \%$ for the same length showed a close relationship as shown in Figure 4.
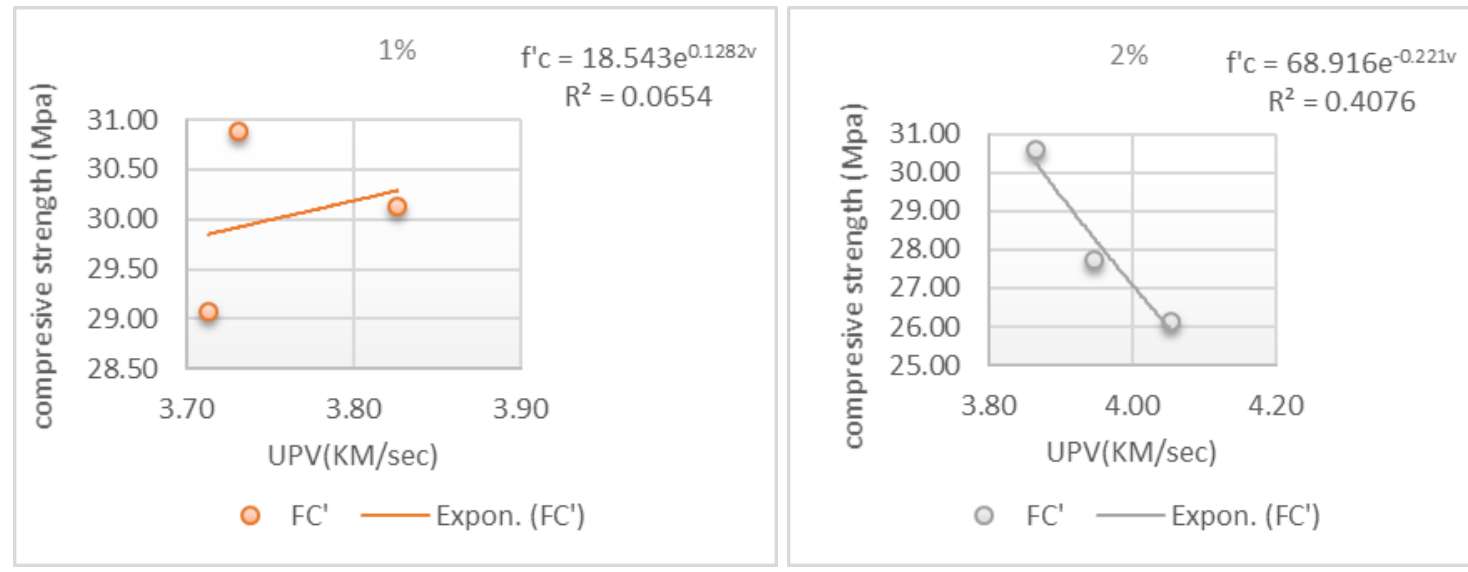


\section{AL-QADISIYAH JOURNAL FOR ENGINEERING SCIENCES}

Vol. 10 , No. 4

ISSN: $1998-4456$

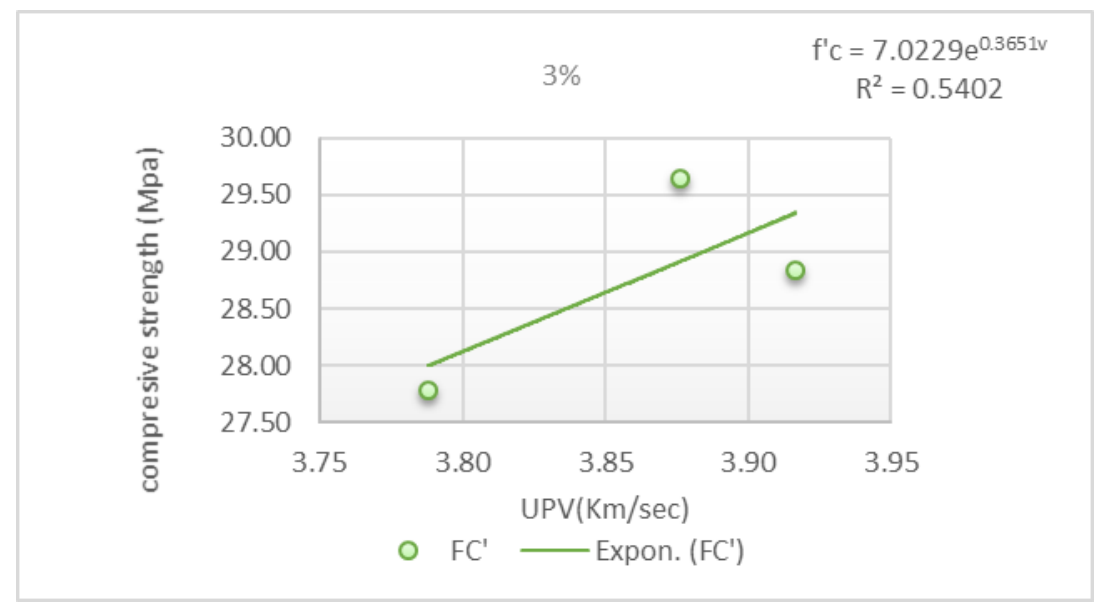

Figure 4: Relationship Between UPV and Compressive Strength for Length $1 \mathrm{~cm}$

Remark: $X$ axis present pulse velocity and $Y$ axis present compressive strength.

The value of compressive strength is accounted by exponential relationship curve with UPV (see Figure 5). The following model (proposed formals) is founded between compressive strength (Mpa) and $\operatorname{UPV}(\mathrm{m} / \mathrm{s})$.

$1 \%$ adding the model is $f^{\prime} \mathrm{c}=18.543 \mathrm{e}^{0.1282 \mathrm{v}}$

$2 \%$ adding the model is $f^{\prime} c=68.916 e^{-0.221 v}$

$3 \%$ adding the model is $f^{\prime} c=7.0229 e^{0.3651 v}$

$$
R=0.0654
$$

$\mathrm{R}=0.4076$

$R=0.5402$

Heterogeneous nature of this composite concrete. For the length $2 \mathrm{~cm}$ with ratio $(1 \%, 2 \%, 3 \%)$ there is appositive relationship but is weak as shown in figure below.

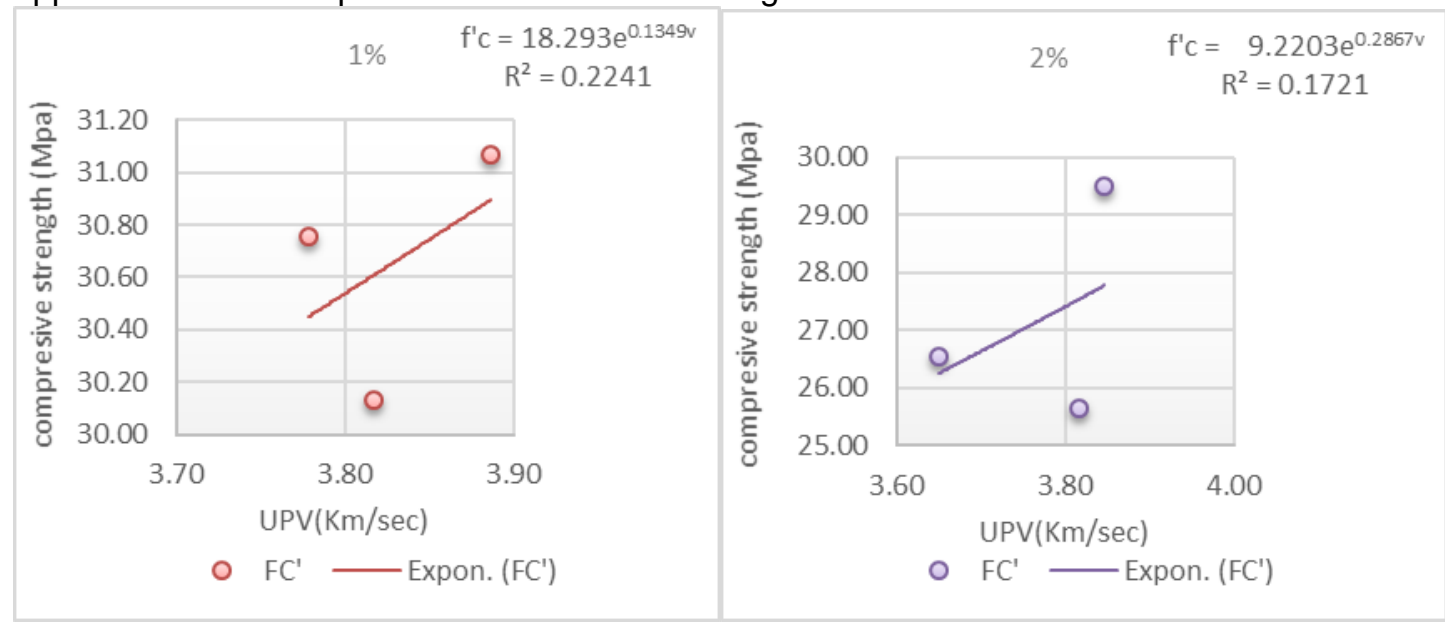




\section{AL-QADISIYAH JOURNAL FOR ENGINEERING SCIENCES}

Vol. 10 , No. 4

ISSN: $1998-4456$

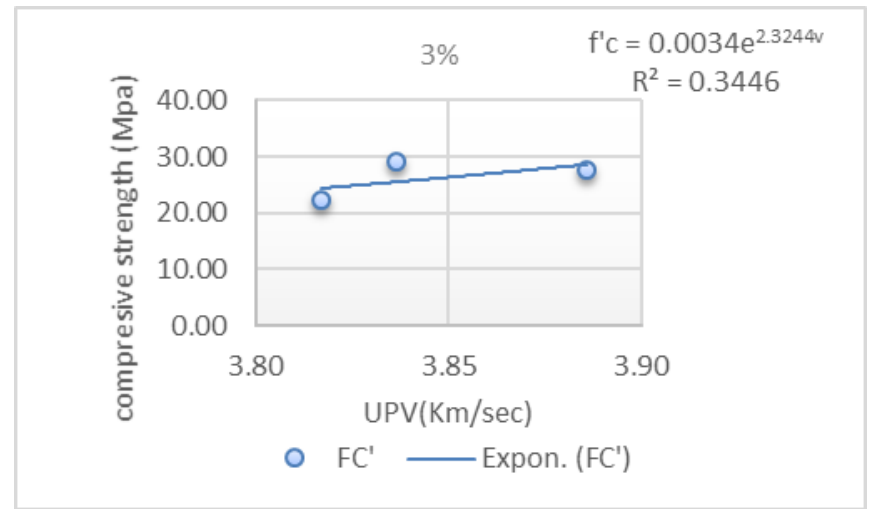

Figure 5: Relationship Curve Between UPV and Compressive Strength for length $2 \mathrm{~cm}$

The following model (proposed formals) is founded between compressive strength (Mpa) and UPV $(\mathrm{m} / \mathrm{s})$

$1 \%$ adding the model is $f^{\prime} c=18.293 e^{0.1349 v}$

$2 \%$ adding the model is $f^{\prime} c=9.2203 e^{0.2867 v}$

$3 \%$ adding the model is $f^{\prime} c=0.0034 e^{2.3244 v}$

$$
R=0.2241
$$

$\mathrm{R}=0.1721$

$$
R=0.3446
$$

For the length $3 \mathrm{~cm}$ with ratio $(1 \%)$ there is a strong related to each other. The correlation factor $(\mathrm{R})$ is equal 0.94 as shown in Figure 6 below:

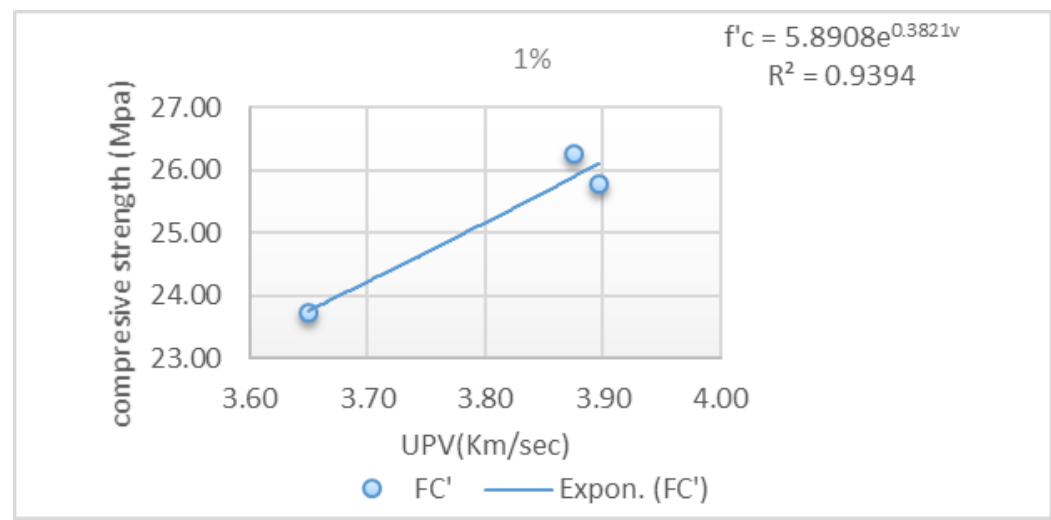

Figure 6: Relationship Curve Between UPV and Compressive Strength for Length $3 \mathrm{~cm}$ and ratio $1 \%$

While the ratio $(2 \%, 3 \%)$ of adding PET for the same length $(3 \mathrm{~cm})$ is weak. As shown in Figure below. 
AL-QADISIYAH JOURNAL FOR ENGINEERING SCIENCES
Vol. 10 , No. 4

ISSN: $1998-4456$

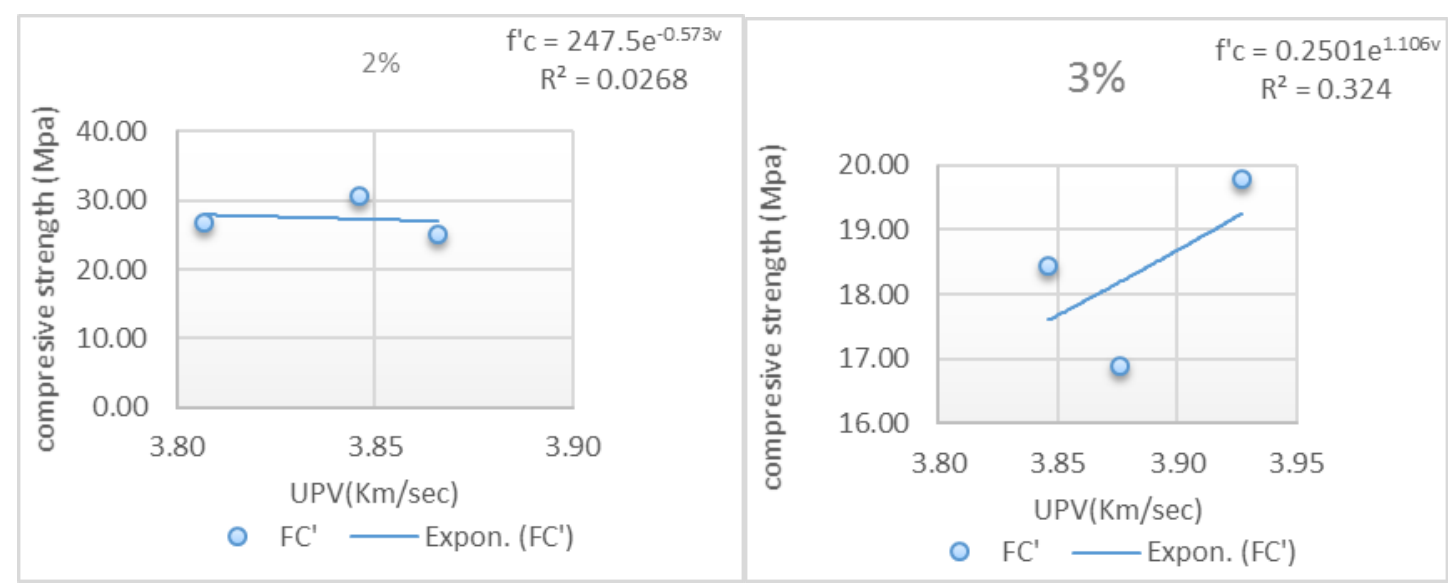

Figure 7: relationship Curve between UPV and compressive strength for length $3 \mathrm{~cm}$ and ratio $2 \%, 3 \%$ $(\mathrm{m} / \mathrm{s})$

The following model (proposed formals) is founded between compressive strength (Mpa) and UPV

$1 \%$ adding the model is $f^{\prime} \mathrm{c}=5.8908 \mathrm{e}^{0.3821 \mathrm{v}}$

$2 \%$ adding the model is $f^{\prime} \mathrm{C}=247.5 \mathrm{e}^{-0.573 \mathrm{v}}$

$3 \%$ adding the model is $f^{\prime} c=0.2501 e^{1.106 v}$
$\mathrm{R}=0.94$

$\mathrm{R}=0.0268$

$\mathrm{R}=0.324$ 


\section{COMPRASION WITH OTHER MODLES}

Al-Nu'man et al.(2015), equations proposed depended on density of course aggregate factor as shown below:

$\begin{array}{lll}F^{\prime} C=8.88 \text { e } 0.42 v & R=0.83 & \text { for } C A=1000 \mathrm{Kg} / \mathrm{m} 3 \\ F^{\prime} C=0.06 \text { e1.6v } & R=0.87 & \text { for } C A=1200 \mathrm{Kg} / \mathrm{m} 3 \\ F^{\prime} C=1.03 \text { e0.87v } & R=0.88 & \text { for } C A=1300 \mathrm{Kg} / \mathrm{m} 3 \\ F^{\prime} C=1.39 \text { e0.78v } & R=0.84 & \text { for } C A=1400 \mathrm{Kg} / \mathrm{m} 3\end{array}$

They considered course aggregate content as a key factor that capable to determining the better relationship between UPV and compressive strength of concrete. In comparison with data of this research, it could be seen the main factor were fibers plastic content. For lengths (1 and 2$) \mathrm{cm}$ increase the ratio of fibers lead to more correlated between UPV and compressive strength. In a more suitable way, the previous equations for both lengths can be rewritten as follows:

For length $1 \mathrm{~cm}$ :

$1 \%$ fibres plastic

$2 \%$ fibres plastic

$3 \%$ fibres plastic

$$
\begin{aligned}
& f^{\prime} c=18.5 e 0.13 v \\
& f^{\prime} c=68.9 e-0.22 v
\end{aligned}
$$$$
f^{\prime} c=7 \text { e } 0.4 v
$$$$
\begin{aligned}
& R=0.07 \\
& R=0.4 \ldots \\
& R=0.5 . . .
\end{aligned}
$$

For length $2 \mathrm{~cm}$ :

$1 \%$ fibres plastic

$$
\begin{gathered}
f^{\prime} c=18 e 0.13 v \\
f^{\prime} c=9 e 0.3 v
\end{gathered}
$$$$
\mathrm{R}=0.2
$$$$
\mathrm{R}=0.2
$$

$3 \%$ fibres plastic

$$
f^{\prime} c=0.003 \text { e2.3v }
$$$$
\mathrm{R}=0.35
$$

But, the length (3) $\mathrm{cm}$ with ratio (1\%) achieve the better relationship between point data and slop curve. The correlation factor was equal 0.94 . It can be say, this length was as a bridge connecting the components of mixture concrete. In addition, it was filling the gaps inside of the mixture. These gave more continuity to the transmission of waves without interruption. Also, in a more suitable way, the previous equations for length (3) $\mathrm{cm}$ can be rewritten as follows:

$\begin{array}{llll}1 \% & \text { fibres plastic } & f^{\prime} c=6 e 0.4 v & R=0.94 \ldots \ldots \ldots(20) \\ 2 \% & \text { fibres plastic } & f^{\prime} c=248 \text { e-0.6v } & R=0.03 \ldots \ldots \ldots(21) \\ 3 \% & \text { fibres plastic } & f^{\prime} c=0.3 e 1.12 v & R=0.32 \ldots \ldots \ldots(22)\end{array}$

For the reference mixture ( $0 \%$ plastic), the proposal formula was

$f^{\prime} c=18 \mathrm{e} 0.14 v \quad R^{2}=0.4$ 
AL-QADISIYAH JOURNAL FOR ENGINEERING SCIENCES
Vol. 10 , No. 4

ISSN: $1998-4456$

\section{COMPARISON E BETWEEN COMPRESSIVE STRENGTH RESULTS FOR}

DESTRUCTIVE AND NON- DESTRUCTIVE TEST

Table below shows the result of destructive and non- destructive test.

Table 6: Result of Destructive and Non- Destructive Test for all Specimens (MPa)

\begin{tabular}{|c|c|c|c|c|c|c|c|c|c|c|c|c|c|c|c|c|c|c|c|}
\hline \multirow{2}{*}{\multicolumn{2}{|c|}{$\begin{array}{c}0 \% \text { (Ref. } \\
\text { Mix) }\end{array}$}} & \multicolumn{6}{|c|}{$1 \mathrm{~cm}$ length } & \multicolumn{6}{|c|}{$2 \mathrm{~cm}$ length } & \multicolumn{6}{|c|}{$3 \mathrm{~cm}$ length } \\
\hline & & \multicolumn{2}{|c|}{$1 \%$} & \multicolumn{2}{|c|}{$2 \%$} & \multicolumn{2}{|c|}{$3 \%$} & \multicolumn{2}{|c|}{$1 \%$} & \multicolumn{2}{|c|}{$2 \%$} & \multicolumn{2}{|c|}{$3 \%$} & \multicolumn{2}{|c|}{$1 \%$} & \multicolumn{2}{|c|}{$2 \%$} & \multicolumn{2}{|c|}{$3 \%$} \\
\hline $\mathrm{F}^{\prime} \mathrm{C}_{d}$ & $F^{\prime} C_{n}$ & $F^{\prime} C_{d}$ & $\mathrm{~F}^{\prime} \mathrm{C}_{\mathrm{n}}$ & $\mathrm{F}^{\prime} \mathrm{C}_{d}$ & $\mathrm{~F}^{\prime} \mathrm{C}_{\mathrm{n}}$ & $\mathrm{F}^{\prime} \mathrm{C}_{d}$ & $F^{\prime} C_{n}$ & $\mathrm{~F}^{\prime} \mathrm{C}_{d}$ & $F^{\prime} C_{n}$ & $\mathrm{~F}^{\prime} \mathrm{C}_{d}$ & $F^{\prime} C_{n}$ & $\mathrm{~F}^{\prime} \mathrm{C}_{d}$ & $F^{\prime} c_{n}$ & $F^{\prime} C_{d}$ & $F^{\prime} C_{n}$ & $F^{\prime} C_{d}$ & $F^{\prime} C_{n}$ & $\begin{array}{l}\mathrm{F}^{\prime} \\
\mathrm{C}_{\mathrm{d}}\end{array}$ & $\begin{array}{l}F^{\prime} \\
c_{n}\end{array}$ \\
\hline 31.1 & 30.8 & 30.3 & 30.1 & 30.2 & 30.6 & 29.3 & 28.8 & 30.9 & 31.1 & 26.3 & 26.5 & 28.5 & 27.6 & 23.8 & 23.7 & 27.2 & 25.0 & $\begin{array}{l}17 \\
.6\end{array}$ & $\begin{array}{r}18 \\
.4\end{array}$ \\
\hline 30.5 & 31.2 & 29.9 & 30.9 & 28.3 & 27.7 & 28.9 & 29.6 & 30.4 & 30.8 & 27.8 & 29.5 & 25.7 & 29.0 & 25.9 & 26.3 & 27.4 & 30.7 & $\begin{array}{l}18 \\
.2\end{array}$ & $\begin{array}{c}16 \\
.9\end{array}$ \\
\hline 30.1 & 29.7 & 29.9 & 29.1 & 25.9 & 26.1 & 28.0 & 27.8 & 30.6 & 30.1 & 27.5 & 25.6 & 24.6 & 22.2 & 26.1 & 25.8 & 28.0 & 26.8 & $\begin{array}{l}19 \\
.3\end{array}$ & $\begin{array}{c}19 \\
.8\end{array}$ \\
\hline
\end{tabular}

Remark: $\mathrm{F}^{\prime} \mathrm{c}_{\mathrm{d}=}$ compressive strength from destructive test.

$\mathrm{F}^{\prime} \mathrm{C}_{\mathrm{n}=}$ compressive strength from non-destructive test.

The data was presented in the graphical shape as shown in the Figures below:

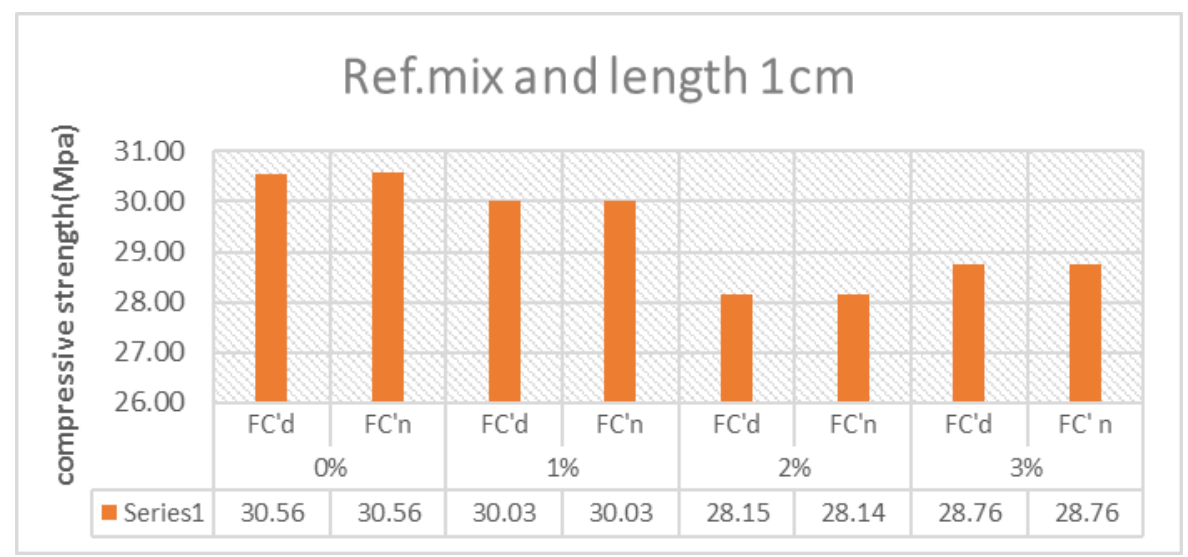

Figure 8: Comparison between Destructive and Non- Destructive Test for Reference mix and Length $1 \mathrm{~cm}$ 


\section{AL-QADISIYAH JOURNAL FOR ENGINEERING SCIENCES}

Vol. 10, No. 4

ISSN: $1998-4456$

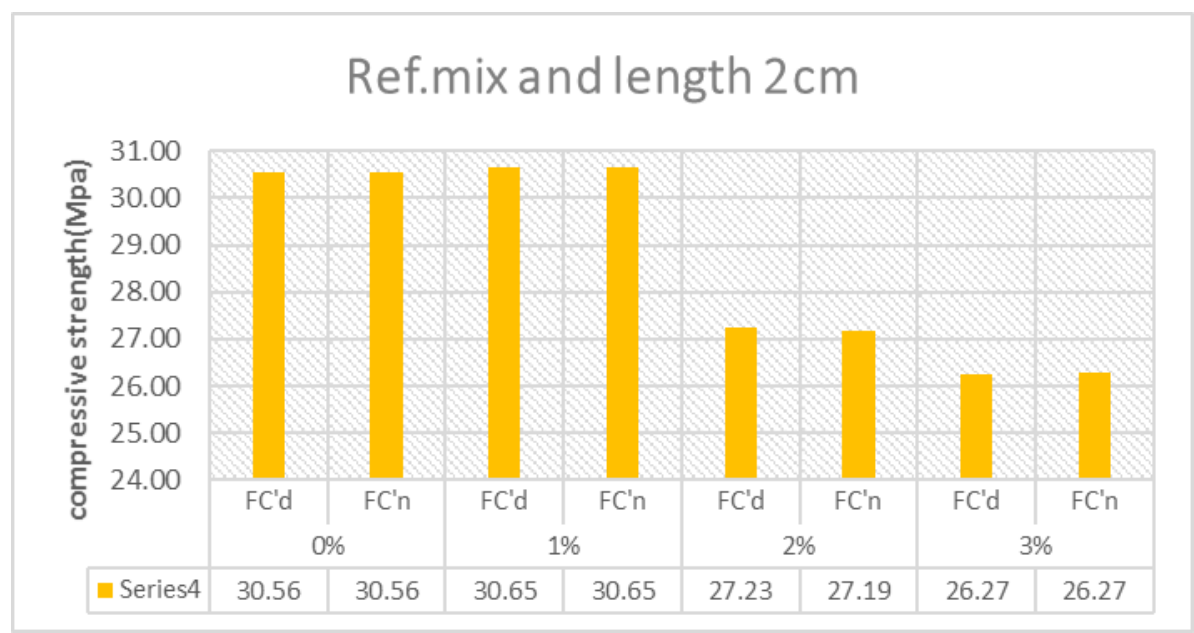

Figure 9: Comparison between Destructive and Non- Destructive Test for the Length $2 \mathrm{~cm}$

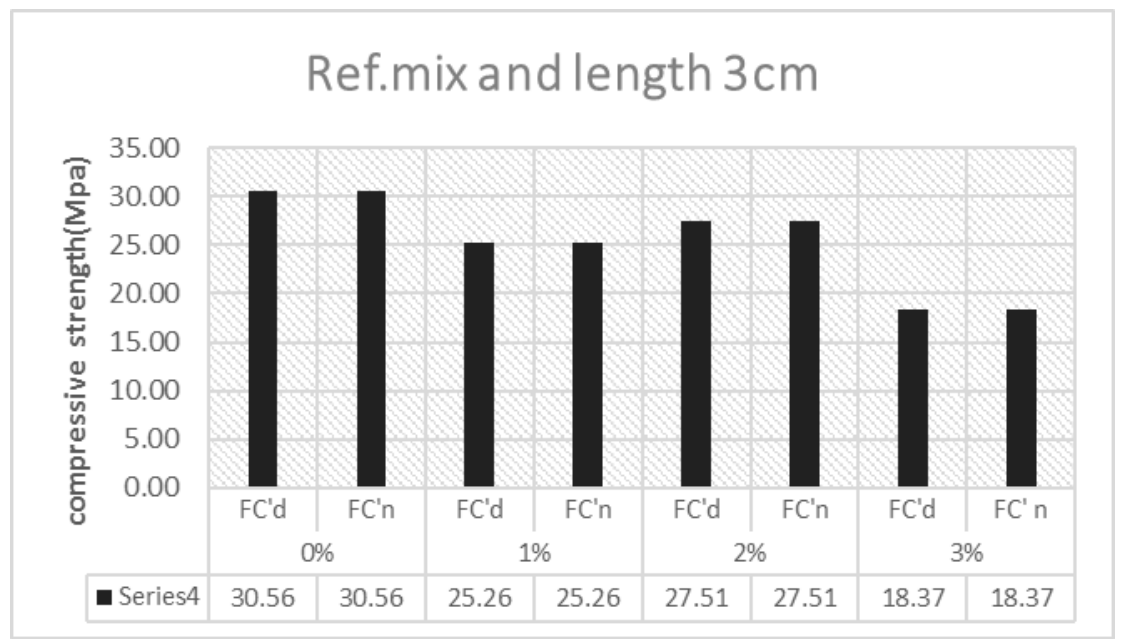

Figure 10: Comparison between Destructive and Non- Destructive Test for the Length $3 \mathrm{~cm}$

It can be seen that, there were a big proximity in results between strength obtained from destructive and non-destructive test. The results show, it can have used UPV to estimate the compressive strength of concrete contain PET by modified the proposal formulas according to mention above. This is a very good indicator to use waste bottle water in concrete.

\section{CONCLUSION AND RECOMMENDATIO}

To evaluate the concrete strength by using UPV test, it must follow the following rule:

UPV should be greater than $3.5 \mathrm{~km} / \mathrm{sec}$ otherwise the concrete considered unsuitable and weak.

The proposal equation to calculate strength of hardened concrete by using UPV was according to the ratio of adding as mentioned above. Therefore, there is no exceptional relationship can be recognized to cover all concrete specimens. 


\section{AL-QADISIYAH JOURNAL FOR ENGINEERING SCIENCES}

Vol. 10, No. 4

ISSN: $1998-4456$

Also, the results of this study show that the ratio $(1 \%)$ for length $(3 \mathrm{~cm})$ gives the closest result between the compression strength calculated from destructive and non-destructive test to clarify the accuracy of the ultrasonic equation test because the correlation factor $(R)$ is equal 0.94 . This beyond to the following:

- This ratio in this length gives homogeneity components of the mixture. This helps to fill the voids without discontinues waves.

- The edge of the fibre in form of zigzag give strong bond between the fiber and the mixture without segregation in components of it. This also gives the waves that are transferred continuously without interruptions.

For future study, the following point are recommended:

- Develop this study, by increased the number of samples to achieve the accuracy of the ultrasonic equation test for this type of concrete.

- Used indirect test method instead of method used in this study to understand their effect on the results.

- Chang the water cement ratio and increased the ratio of adding plastic as a ratio of the cement weight

\section{REFERENCES}

1. Ammash, H. K., Hemzah, S. A., \& Jasim, R. (2017). Effect of Using Plastic Waste on Mechanical Properties of Concrete. Menoufia University, Faculty of Engineering. Ninth Conference of Sustainable Environmental Development.

2. Al-Nu'man, B. S., Aziz, B. R., Abdulla, S. A., \& Khaleel, S. E. (2015). Compressive Strength Formula for Concrete using Ultrasonic Pulse Velocity. International Journal of Engineering Trends and Technology (IJETT). 26(1):8-13.

3. Benosman, A. S., Taïbi, H., Mouli, M., Senhadji, Y., \& Bahlouli, I. (2016) Destructive and NonDestructive Tests of PET-Mortar Composites: Characterization by TG/dTG Analysis. Communication Science \& technology, 16: 89-99.

4. Gül, R., Demirboğa, R., \& Güvercin, T. (2006). Compressive strength and ultrasound pulse velocity of mineral admixtured mortars. Indian Journal of Engineering and Material Sciences, 13:18-24.

5. Iraqi Specification IOS 45 - 1984.

6. Iraqi Specification, No.5,1984, Portland Cement.

7. Lorenzi, A., Tisbierek, F. T., \& Silva, L. C. P. (2007, October). Ultrasonic pulse velocity análysis in concrete specimens. In IV Conferencia Panamericana de END, Buenos Aires.

8. Rajakumar, I., Senthilkumar, G., Kumar, M. A., Balaji, R., \& Yuvaraju, N. (2016). Non Destructive analysis on fiber reinforced concrete using waste plastic fiber. International Journal of Applied Science and Engineering Research, 5(1):1-9.

9. Safinia, S. and Alkalbani,A. (2016) Use of Recycled Plastic Water Bottles in Concrete Blocks, In Procedia Engineering, Volume 164, pp 214-221. 